\title{
Germinating seeds or bulbils in 87 of 113 tested Arctic species indicate potential for ex situ seed bank storage
}

\author{
Inger Greve Alsos • Eike Müller • \\ Pernille Bronken Eidesen
}

Received: 14 October 2012/Revised: 8 February 2013/Accepted: 13 February 2013/Published online: 26 March 2013

(C) The Author(s) 2013. This article is published with open access at Springerlink.com

\begin{abstract}
Arctic plant species are expected to lose range due to climate change. One approach to preserve the genetic and species diversity for the future is to store propagules in seed vaults. However, germinability of seeds is assumed to be low for Arctic species. We evaluated ex situ storage potential of 113 of the 161 native angiosperms of Svalbard by studying seed ripening and germination. Seeds or bulbils were collected, and germinability was tested after one winter of storage in the Svalbard Global Seed Vault. Twenty-six of the species did not produce ripe propagules, 8 produced bulbils, and 79 produced seeds. Bulbils sprouted to high percentages. Seeds of 10 species did not germinate, 22 had low germination $(<20 \%), 34$ had germination of $21-70 \%$, and 13 had high germination percentages $(>70 \%)$. More than $70 \%$ of the species belonging to Asteraceae, Brassicaceae, Caryophyllaceae, Juncaceae, Rosaceae, and Saxifragaceae germinated. Cold tolerant, common species had higher germination percentages than relatively thermophilous, rare species. Germination percentages were six times higher than observed
\end{abstract}

Electronic supplementary material The online version of this article (doi:10.1007/s00300-013-1307-7) contains supplementary material, which is available to authorized users.

I. G. Alsos ( $₫)$

Tromsø University Museum, 9037 Troms $\emptyset$, Norway

e-mail: inger.g.alsos@uit.no

I. G. Alsos · E. Müller · P. B. Eidesen

The University Centre in Svalbard, Post Office Box 156,

9171 Longyearbyen, Norway

E. Müller

Department of Arctic and Marine Biology,

Faculty of Biosciences, Fisheries and Economics,

University of Troms $\varnothing, 9037$ Troms $\varnothing$, Norway in $1969(n=51)$ and 0.7 times that observed in 2008 $(n=22)$, indicating that recent climate warming improves germination in the Arctic. While in situ conservation is of vital importance, ex situ conservation in seed banks is a potential complementary conservation strategy for the majority of Arctic vascular plant species. For species that did not germinate, other methods for ex situ conservation should be sought, for example, growing in botanical gardens.

Keywords Arctic - Bulbils · Conservation ·

Seed germination $\cdot$ Rare $\cdot$ Red List

\section{Introduction}

Climate change, invasive species, land use, and other human impact may threaten a large part of the words flora (Sala et al. 2000; Pimentel 2011; Thuiller et al. 2011). To meet these challenges, many nations now collect and bank seeds for restoration purposes, ex situ conservation, and relocation (Vitt et al. 2010). While large efforts are made to bank the entire flora of, for example, the USA and UK (http://www.nps.gov/plants/sos/, http://www.kew.org/), the Arctic flora is so far underrepresented in these seed banks. A relatively low proportion of the Arctic flora is rare and considered endangered (Talbot et al. 1999; Elven et al. 2011); however, even common species may be threatened as the expected profound changes in Arctic climate (ACIA 2006) may reduce species ranges by $40 \%$ followed by considerable loss of genetic diversity (Alsos et al. 2012a). Also, increased human activities combined with climate change increase the risk of establishment of alien species (Ware et al. 2012), which may have negative effect on the native flora. A prerequisite for storing seeds is that they are 
viable, but knowledge of germinability of seeds and bulbils of the Arctic flora is still scarce. In earlier studies, the proportion of species producing viable seeds and their germination percentages were found to be lower in the Arctic than in other regions (Sørensen 1941; Bliss 1958; Eurola 1972; Bell and Bliss 1980). However, a recent study of 22 Arctic species indicated increased germination, partly owing to increased temperature (Müller et al. 2011). Knowledge of germinability of seeds and bulbils for more species is required to evaluate if Arctic flora can be additionally conserved ex situ in seed vaults.

Many factors are likely to influence seed production and viability in the Arctic. Two main factors are the short growing season and the low temperatures, which are especially pertinent for relatively thermophilous species that may only be able to set viable seeds in infrequent years of high summer temperatures (Sørensen 1941; Wookey et al. 1995; Alsos et al. 2003). Low temperatures also reduce pollinator activity (Hodkinson et al. 1998) and drive the reproduction mode towards asexuality (Peck et al. 1998), which may influence successful reproduction and seed set. Although some species reproduce with asexual (apomictic) seeds, many essentially rely on runners or bulbils for dispersal (Wehrmeister and Bonde 1977; Murray 1987; Dormann et al. 2002). Bulbils are analogous to seeds in terms of dispersal, but they are generally more vulnerable as they lack the protection of a seed coat. Thus, their prospects for long-term storage may be low (Walck et al. 2010). However, while asexual reproduction is successful and important in the Arctic flora, it is rarely exclusive, and ripe seeds of most species may be found in favourable sites or years, even for those species mainly reproducing by bulbils (Murray 1987).

The flora of the Arctic archipelago Svalbard is typical for the mid-to-high Arctic flora as insect-pollinated herbs, in terms of species number, are dominating (Brochmann and Steen 1999). Different from most low-to-mid Arctic sites, there are no bumble bees on the archipelago, and pollination is mainly by flies (Diptera) (http://svalbardinsects.net/, Coulson and Refseth 2004). It is assumed that 97 of 161 angiosperms in Svalbard reproduce mainly sexually (Brochmann and Steen 1999). In the most comprehensive study on germination from Svalbard, 19 of 63 mainly common species did not germinate, whereas those that did germinate generally had low germination rates (Eurola 1972). However, more recent studies on five (Hagen 2002) and 22 (Müller et al. 2011), mainly common species, show higher germination rates. Very rare (1-4 localities) and rare (5-25 localities) species constitute $36 \%$ of the flora of Svalbard (Brochmann and Steen 1999). Due to the geographic isolation of the archipelago, a separate evaluation of threats to the species has been made, and 54 of them have been redlisted; 10 as critically endangered, 10 as endangered, and 17 as near threatened (Solstad et al. 2010). The majority of rare species are relatively thermophilous (Elven and Elvebakk 1996; Engelskjøn et al. 2003). These may have colonized the archipelago during the Holocene hypsithermal 8000-4000 BP (Alsos et al. 2002, 2007), when the climate was $1-2{ }^{\circ} \mathrm{C}$ warmer than today (Birks et al. 1994), and may persist in the current climate predominately by clonal growth (Alsos et al. 2002). With a warming climate, recruitment of the thermophilous species may also increase, as has been observed for common Arctic species (Müller et al. 2011).

The aims of this study were to (1) collect seeds or bulbils from as many species as possible of Svalbard's native vascular flora, (2) test whether germinability of species is appropriate for ex situ conservation in seed banks, (3) test whether germinability is related to thermal requirements, rarity, or ability to reproduce clonally, and (4) compare with earlier studies to see if germination has recently increased. New test of germination is planned again after 5 and 10 years. However, as we present data on 55 species not studied in Svalbard before, and as this is the largest study of germination in Arctic plants since Sørensen's studies in Greenland (Sørensen 1941), we present the results of germination after 1 year of storage here.

\section{Materials and methods}

\section{Collection and storage of seeds}

Seeds were collected in paper bags between 27 August and 19 September 2008 in the Isfjorden area of Svalbard (Appendix 1 of Electronic supplementary material, Fig. 1). If possible, seeds were shaken out of the plants to ensure that only mature seeds were collected. However, if the plants were wet, seed capsules were collected and left in paper bags at $5-8{ }^{\circ} \mathrm{C}$ in $35 \%$ relative humidity (RH) to dry. Seeds that were obviously not ripe were not collected. Seeds of species which did not seem $100 \%$ ripe (Arnica angustifolia, Carex glacialis, Carex marina ssp. pseudolagopina, Coptidium pallasii, Micranthes hieracifolia ssp. hieracifolia, Petasites frigidus ssp. frigidus, and Ranunculus wilanderi) were left in paper bags at $5-8{ }^{\circ} \mathrm{C}$ until 19 September to permit ripening, after which they were assumed to be ripe. Nuts of Empetrum nigrum were washed out of the berries. Herbarium vouchers were collected and deposited at Troms $\varnothing$ University Museum (TROM).

For this first germination test following one winter of storage, and also for each of two tests planned for the future, seeds were counted and placed in sealed aluminium bags. The bags were placed at $-2{ }^{\circ} \mathrm{C}$ on 15 or 24 September 2008 and stored outside at about $-6{ }^{\circ} \mathrm{C}$ from 1 October. A temperature logger (Tinytag Plus 2 TGP-4020) 


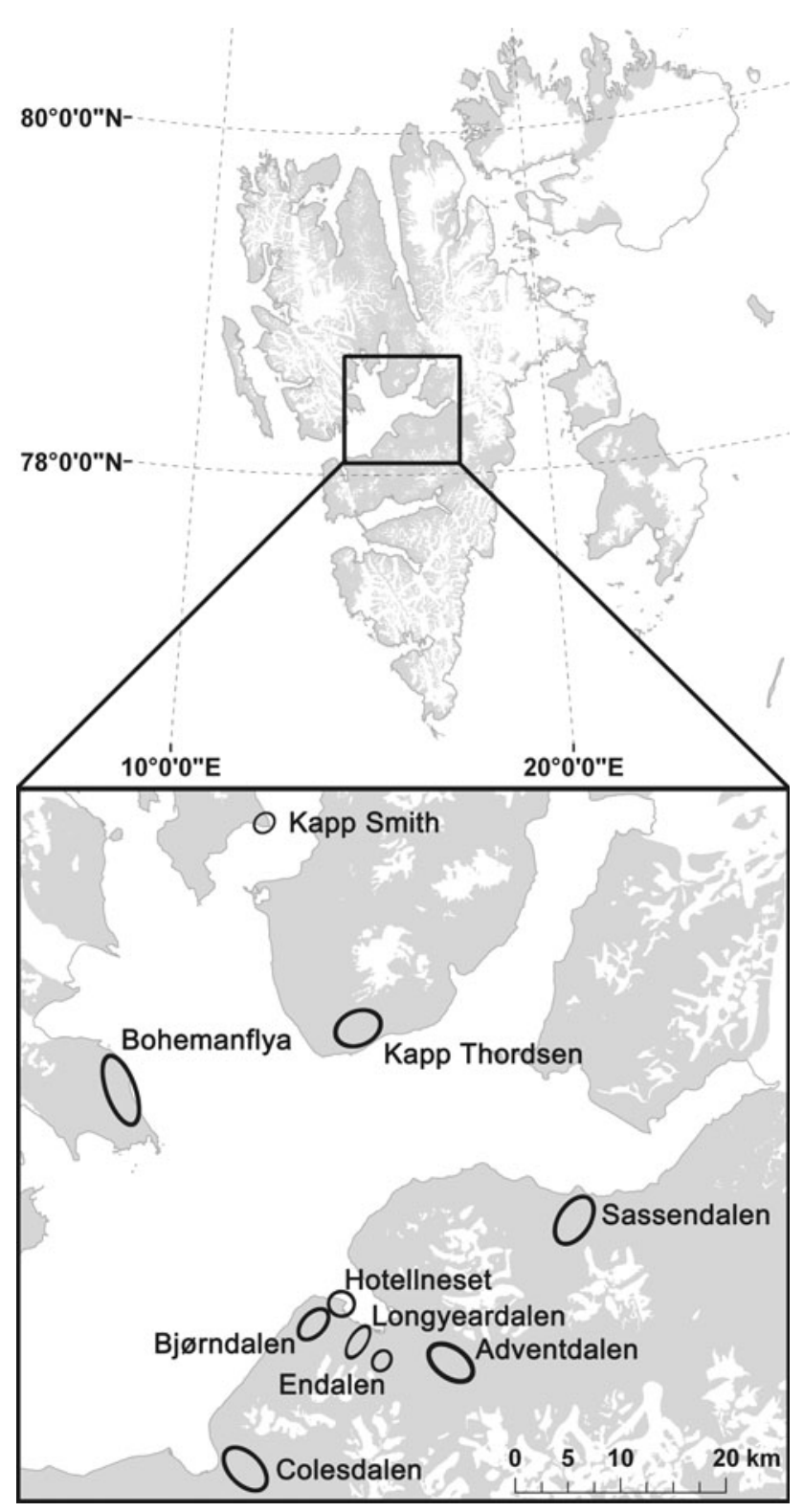

Fig. 1 Sites where seeds were collected for studies of germination and for long-term storage in the Svalbard Global Seed Vault

was placed in one of the boxes 2 October. The temperature dropped to $-10{ }^{\circ} \mathrm{C}$ during the night of 2 October. On 3 October, the seed boxes were placed in the Svalbard Global Seed Vault where the temperature was about $-14{ }^{\circ} \mathrm{C}$. The box with the seeds for germination trials was taken out of the Svalbard Global Seed Vault on 27 April 2009. Thus, this first year of storage resembles what seeds of Arctic species experience under natural conditions as they ripe in autumn and normally do not germinate within the season they are produced (Söyrinki 1939; Sørensen 1941). As a period of frost usually enhance germination in Arctic species (Söyrinki 1939), no fresh seeds were germinated.
Stratification and germination of seeds

Usually $3 \times 50$ seeds of each species were put in Petri dishes $(9 \mathrm{~cm}$ in diameter) with $10 \%$ agar solution and covered with a lid to ensure high moisture conditions. Thereafter, the seeds were either stratified for a period at $1{ }^{\circ} \mathrm{C}$, or put directly to germination at $24 \mathrm{~h} 10^{\circ} \mathrm{C}, 24 \mathrm{~h}$ $20{ }^{\circ} \mathrm{C}$, or $12 \mathrm{~h} 10^{\circ} \mathrm{C}$ and $12 \mathrm{~h} 20^{\circ} \mathrm{C}$ (Appendix 2 of Electronic supplementary material). Stratification and germination conditions selected for each species were based on an extensive review of seed germination trials of the same species or genera (not shown), or after recommendations from Lindsay Robb at the Millenium Seed Vault (personal communication). The light temperature was 4,000 K (Osram $35 \mathrm{~W}, 840 \mathrm{HE}$ ) and the brightness was $3,300 \mathrm{~lm}$ (manufacturer's information). The proton flux was approximately $40 \mu \mathrm{mol}$ per square meter per second measured with a quantum flux sensor at the level of the seeds. If the germination percentage obtained was low, but the seeds still seemed viable, a new germination test was attempted following an additional period of stratification (Appendix 2 of Electronic supplementary material). Only final germination percentages are given in Table 1.

Table 1 Germination percentages of species from the Arctic Archipelago of Svalbard

\begin{tabular}{|c|c|}
\hline Species & $\%$ \\
\hline Alopecurus borealis & 0 \\
\hline Arabis alpina & 6.6 \\
\hline Arctagrostis latifolia (EN) & - \\
\hline Arctophila fulva & - \\
\hline Arenaria pseudofrigida & 30.5 \\
\hline Arnica angustifolia & 0.7 \\
\hline Betula nana var. tundrarum (NT) & 0 \\
\hline Bistorta vivipara ${ }^{\mathrm{a}}$ & 100.0 \\
\hline Braya glabella ssp. purpurascens & 60.3 \\
\hline Calamagrostis neglecta ssp. groenlandica & - \\
\hline Campanula rotundifolia ssp. gieseckiana (VU) & - \\
\hline Cardamine polemonioides & - \\
\hline Carex bigelowii ssp. ensifolia (CR) & - \\
\hline Carex fuliginosa ssp. misandra & 0 \\
\hline Carex glacialis (VU) & 8.1 \\
\hline Carex krausei $(\mathrm{VU})$ & 67.1 \\
\hline Carex lachenalii & 14.1 \\
\hline Carex lidii (VU) & - \\
\hline Carex marina ssp. pseudolagopina $(\mathrm{VU})$ & 0 \\
\hline Carex maritima & 2.7 \\
\hline Carex nardina ssp. hepburnii & 0 \\
\hline Carex parallela ssp. parallela & - \\
\hline Carex rupestris & 2.0 \\
\hline Carex saxatilis ssp. laxa & - \\
\hline
\end{tabular}


Table 1 continued

Species $\%$

Carex subspathacea

$\%$

Carex ursina

Cassiope tetragona ssp. tetragona

Cerastium arcticum

Cerastium regelii ssp. caespitosum

Chrysosplenium tetrandrum

Cochlearia groenlandica

Coptidium lapponicum

Coptidium pallasii (NT)

Deschampsia alpina ${ }^{\mathrm{a}}$

Deschampsia sukatschewii ssp. borealis

Draba alpina

Draba arctica ssp. arctica

Draba glabella

Draba lactea

Draba nivalis

Draba rupestris (syn. D norvegica)

Draba subcapitata

Dryas octopetala

Dupontia fisheri morph "psilosantha"

Empetrum nigrum

Erigeron humilis

Eriophorum $\times$ sorensenii $(\mathrm{NT})$

Eriophorum scheuchzeri ssp. arcticum

Eriophorum triste

Euphrasia wettsteinii (EN)

Festuca baffinensis

Festuca brachyphylla (VU)

Festuca edlundiae

Festuca rubra ssp. richardsonii

Festuca viviparoidea ssp. viviparoidea ${ }^{\mathrm{a}}$

Hierochloë alpina

Honckenya peploides ssp. diffusa (NT)

Juncus albescens

Juncus biglumis

Koenigia islandica

Luzula confusa

Luzula nivalis

Luzula wahlenbergii (NT)

Mertensia maritima ssp. tenella

Micranthes foliolosa ${ }^{\mathrm{a}}$

Micranthes hieracifolia ssp. hieracifolia

Micranthes nivalis

Minuartia biflora

Minuartia rossii (NT)

Minuartia rubella

Oxyria digyna

Papaver dahlianum
Table 1 continued

\begin{tabular}{lc}
\hline Species & $\%$ \\
\hline Pedicularis dasyantha var. dasyantha & 0
\end{tabular}

Pedicularis hirsuta

17.3

Petasites frigidus ssp. frigidus 0

$33.8 \quad$ Phippsia algida $\quad 2.4$

- Phippsia concinna $\quad 95.7$

$25.0 \quad$ Pleuropogon sabinii (NT)

14.2

Poa abbreviata ssp. abbreviata

Poa alpina var. vivipara ${ }^{\mathrm{a}}$

Poa arctica ssp. arctica sem.

Poa glauca

Poa pratensis ssp. alpigena seminiferous

Poa pratensis ssp. alpigena viv. ${ }^{\mathrm{a}}$

Polemonium boreale

Potentilla hyparctica ssp. hyparctica

Potentilla pulchella $\begin{array}{ll}\text { Puccinellia vahliana (NT) } & 52.0\end{array}$

Ranunculus hyperboreus ssp. arnelli $\quad 40.1$

Ranunculus nivalis $\quad 49.2$

Ranunculus wilanderi (EN) $\quad 27.8$

Rubus chamaemorus (CR) -

Sagina nivalis $\quad 97.3$

Salix polaris $\quad 83.8$

Salix reticulata

Saxifraga aizoides

Saxifraga cernua ${ }^{\text {a }} \quad 94.5$

Saxifraga cespitosa ssp. cespitosa $\quad 13.4$

Saxifraga hirculus ssp. compacta $\quad 4.1$

Saxifraga oppositifolia ssp. oppositifolia $\quad 61.1$

Saxifraga platysepala

Saxifraga svalbardensis ${ }^{\mathrm{a}} \quad 88.2$

Silene acaulis ssp. acaulis $\quad 77.3$

Silene involucrata ssp. furcata $\quad 66.9$

Silene uralensis ssp. arctica $\quad 26.2$

Stellaria humifusa $\quad 94$

Stellaria longipes taxon crassipes -

Taraxacum arcticum agg. $\quad 55.2$

Trisetum spicatum ssp. spicatum $\quad 32.4$

Vaccinium uliginosum ssp. microphyllum (CR)

Species in bold are redlisted. Redlist categories (in brackets) are $C R$ critical endangered, $E N$ endangered, $V U$ vulnerable, and $N T$ near threatened. ${ }^{a}$ Bulbil. Species without ripe seeds are listed with "-”

Characteristics of species

Type of propagule (seeds or bulbils) and family was noted for all species. Rarity in Svalbard (very rare $=1-4$
Ranunculus pygmaeus $\quad 69.0$ 
populations, rare $=5-25$ populations, and common) was given according to Elven and Elvebakk (1996) except for two species where the taxonomy later has been clarified; Carex bigelowii ssp. ensifolia is found one place (Solstad et al. 2010) and F. edlundia is common (Alsos et al. 2012a). We classified the species into five groups of thermophily (strongly, distinctly, moderately, weakly, indifferent) according to Elvebakk (1989) except for species not classified by him: Carex krausei, Eriophorum $\times$ soerensenii, Festuca edlundia, Ranuculus wilanderi, Saxifraga rivularis ssp. rivularis, and S. svalbardensis. For these species, we used Elvebakk's criteria combined with known distribution (Alsos et al. 2012a). Clonal modes of propagations were according to Brochmann and Steen (1999) except for $C$. bigelowii ssp. ensifolia which was according to Brooker et al. (2001). Species producing runners, stolons, or bulbils were classified as clonal, and others as nonclonal (including species with apomictic seeds). No data on reproduction were available for Eriophorum $\times$ sorensenii. Nomenclature follows Elven et al. (2011).

\section{Comparison with other studies}

There are four previous studies on germination from Svalbard that includes a minimum of three species. Eurola (1972) collected seeds in the vicinity of Longyearbyen and the climatically similar location Svea in 1969. In addition, he collected some seeds along altitudinal gradients. His mean values from Longyearbyen and Svea are used if he collected the species there; otherwise, data from other sites were used. Hagen (2002) and Müller et al. (2011) collected seeds in the vicinity of Longyearbyen in 1998 and 2008, respectively. For Müller, germination percentages obtained at $18{ }^{\circ} \mathrm{C}$ in the phytotron were used. Hagen (2002) displays the germination in graphs and no exact percentages are given. Alsos et al. (2003) collected seeds of three thermophilous species in Colesdalen; none of them germinated.

To compare with another Arctic region of similar climate, we used the data of Sørensen (1941). He collected seeds of 99 species in 1934 at Eskimonæs, Northeastern Greenland, and germinated them in the field at the same site. He further collected bulbils of two species and noted lack of ripe seeds in 22 species. This is the only extensive germination study we are aware of which is in the same bioclimatic subzone (subzone C) as the sampling sites in Svalbard. Comparisons were done at species level ignoring that for some species different subspecies occur in the two regions.

\section{Statistics}

To test the strength of association between family and thermophily, we initially applied a linear model. However, as the model fit was very poor, we treated thermophily as a variable with five categories and applied a Cramer's V (Acock and Gordon 1979). To test the strength of other two-way association between rarity, thermophily, family, and clonality, we applied Chi square tests for $2 \times \mathrm{X}$ contingency tables. Only families with at least three species represented were included. Standard deviations for germination percentages of each species were calculated with a formula for binomial data (Collett 2003).

To assess the effect of propagule type, thermophily, rarity, clonality, and family on germination, we applied generalized linear models (GLM) with a quasibinomial error distribution. Each GLM was set up with one predictor variable. Further, to test the influence of the above-mentioned predictor variables also on the proportion of species with ripe seeds, each species that germinated was marked as successful and each species that did not germinate, or for which no seed was initially found, was marked as not successful.

To test for interactions between predictor variables and estimate the biological effect of these variables on germination, a linear mixed effect model (LME) with a binomial error distribution was fitted to the data. As rarity and thermophily was associated, we choose the predictor variable with less levels (rarity). Rarity (levels: rare and common) and main reproduction mode (levels: clonal reproduction present and clonal reproduction absent) were used as categorical predictor variables with fixed effects and plant family as random effect with species nested within family as random effect. For these, the $\mathrm{R}$ package lme 4 version 0.999999-0 (http://lme4.r-forge.r-project.org/) was used. All calculations were done in R 2.14.0 (R Core Team 2012).

\section{Results}

Of the 113 species observed in this study, 79 had ripe seeds and 8 had bulbils (Table 1). In addition, 26 species were without ripe seeds (Table 1). All species with bulbils germinated at high percentages (71-100\%).

Of the 79 species with seeds, seeds of 10 species did not germinate; 12 species had very low germination $(<10 \%)$; 10 had low germination (10-20\%); 23 had intermediate germination $(21-50 \%) ; 11$ had high germination (51-70\%); and 13 had very high germination (>70\%, Table 1). The mean germination was $35 \%$.

Of the 24 species that germinated to $>50 \%$, all are common in Svalbard with the exception of two species (Appendix 3 of Electronic supplementary material). Five of the 13 species showing very high $(>70 \%)$ germination were of the genus Draba. Surprisingly, the two strongly thermophilous species Juncus albescens and Carex krausei had germination percentages of 91 and $67 \%$, respectively.

Among the 36 species that either did not germinate or for which no ripe seeds were observed, 22 were strongly or 
distinctly thermophilous species, and seven were rare, and six very rare (Appendix 3 of Electronic supplementary material). Of the ten species that did not germinate, there were three species of Carex, two of Coptidium, one graminoid (Alopecurus borealis), one shrub (Betula nana var. tundrarum), one Asteraceae (Petasites frigidus ssp. frigidus), and the hemiparasites Euphrasia wettsteinii and Pedicularis dasyantha var. dasyantha (Table 1).

We found seeds in all except four non-clonal species: Deschampsia sukatschewii ssp. borealis, Minuartia biflora, Polemonium boreale, and Saxifraga aizoides (Table 1, Appendix 3 of Electronic supplementary material). Further, seeds of six non-clonal species did not germinate. Seven of the non-clonal species without germinable seeds were common, one rare, and two very rare (Appendix 3 of Electronic supplementary material).

Assumed ripe seeds were found in 12 redlisted species and seeds of eight of these germinated. Another eight redlisted species were examined but had no ripe seeds (Table 1).

\section{Effect of species characteristics}

There was an association between thermophily and rarity $\left(\chi^{2}=43.80, d f=5, p<0.001\right)$, as all rare species were strongly thermophilous or distinctly thermophilous
(Appendix 3 of Electronic supplementary material). There was also an association between thermophily and family (Cramer's V $=0.43, \mathrm{M} ; N=10 ; 5, p=0.042$ ). There was no association between family and rarity $\left(\chi^{2}=7.16\right.$, $d f=9, p=0.620)$. Further, there was no association between clonality and rarity $\left(\chi^{2}=0.012, d f=1\right.$, $p=0.913)$, family $\left(\chi^{2}=15.08, d f=9, p=0.089\right)$, or thermophily $\left(\chi^{2}=4.55, d f=4, p=0.337\right)$.

Plant family had a significant influence on germination percentages (Table 2). The applied GLM with plant family as predictor variable for germination percentages had the lowest deviance of all used models (Table 2), and thus, plant family had a comparatively high influence on germinability of seeds. The family that had the highest germination rate was Brassicaceae $(57 \%)$, followed by Caryophyllaceae (46\%) and Juncaceae (44\%). Scrophulariaceae $(6 \%)$ had the lowest germination percentages, followed by Asteraceae (18\%) and Cyperaceae (20\%; Fig. 2; Table 2). Germination, however, increased with increasing cold tolerance of the species. Also germination percentages were higher for common species than for rare species (Fig. 2; Table 2). Thermophile species either did not produce seeds (e.g. Betula nana and Rubus chamaemorus) or germinated to comparatively low percentages (e.g. Arnica angustifolia and Carex glacialis,

Table 2 Effect of species characteristics on germination percentages of seeds from Svalbard

\begin{tabular}{|c|c|c|c|c|c|c|c|c|c|c|}
\hline $\begin{array}{l}\text { Predictor } \\
\text { variable }\end{array}$ & Level & $\begin{array}{l}\text { Germination } \\
(\%)\end{array}$ & $\begin{array}{l}\text { Lower } \\
\text { SE }\end{array}$ & $\begin{array}{l}\text { Upper } \\
\text { SE }\end{array}$ & $\begin{array}{l}\text { Number of } \\
\text { Species }\end{array}$ & $n$ & $d f$ & $\begin{array}{l}\text { Residual } \\
\text { deviance }\end{array}$ & $F$ value & $p$ \\
\hline \multirow[t]{2}{*}{ Propagules } & Bulbils & 94.09 & 90.24 & 96.48 & 8 & 23 & 254 & $5,509.6$ & 87.54 & $<0.001$ \\
\hline & Seeds & 35.03 & 33.09 & 37.01 & 79 & 233 & & & & \\
\hline \multirow{2}{*}{$\begin{array}{l}\text { Clonal } \\
\text { reproduction }\end{array}$} & Clonal & 25.32 & 21.87 & 29.12 & 20 & 233 & 231 & $5,213.4$ & 8.26 & 0.004 \\
\hline & Non-clonal & 38.32 & 35.99 & 40.71 & 59 & & & & & \\
\hline Thermophily & Continuous $1-5$ & $4.4 x+15.87^{\mathrm{a}}$ & $12.78^{\mathrm{a}}$ & $19.54^{\mathrm{a}}$ & 79 & 233 & 231 & $4,957.1$ & 22.03 & $<0.001$ \\
\hline \multirow[t]{2}{*}{ Rarity } & Rare & 20.46 & 16.77 & 24.72 & 15 & 43 & 231 & $5,129.6$ & 12.58 & $<0.001$ \\
\hline & Common & 38.26 & 36.03 & 40.54 & 64 & 190 & & & & \\
\hline \multirow[t]{10}{*}{ Family $^{\mathrm{b}}$} & Asteraceae & 18.32 & 12.21 & 26.55 & 4 & 11 & 216 & $3,966.6$ & 5.43 & $<0.001$ \\
\hline & Brassicaceae & 56.98 & 51.72 & 62.08 & 10 & 30 & & & & \\
\hline & Caryophyllaceae & 46.32 & 41.02 & 51.71 & 10 & 29 & & & & \\
\hline & Cyperaceae & 20.15 & 16.31 & 24.62 & 11 & 33 & & & & \\
\hline & Juncaceae & 43.84 & 36.63 & 51.31 & 5 & 15 & & & & \\
\hline & Poaceae & 35.02 & 30.43 & 39.90 & 12 & 36 & & & & \\
\hline & Ranunculaceae & 29.98 & 23.26 & 37.69 & 6 & 16 & & & & \\
\hline & Rosaceae & 52.06 & 42.47 & 61.51 & 3 & 9 & & & & \\
\hline & Saxifragaceae & 31.10 & 25.57 & 37.23 & 7 & 21 & & & & \\
\hline & Scrophulariaceae & 5.91 & 2.70 & 12.41 & 3 & 9 & & & & \\
\hline
\end{tabular}

Test statistics for generalized linear models (GLMs) with quasibinomial error distribution are given for all characteristics. Species indicates the number of species included in the particular level, $n$ is the total number of replicates included at a particular level. Test statistics is ANOVA with $F$ tests. Species reproducing by bulbils are only included in the first test, whereas species without ripe seeds in the year of study were excluded from all tests. Germination percentages and SE were backtransformed from the quasibinomial models

${ }^{\text {a }}$ Germination percentage and SE of the intercept

b Plant families with less than three species are excluded 

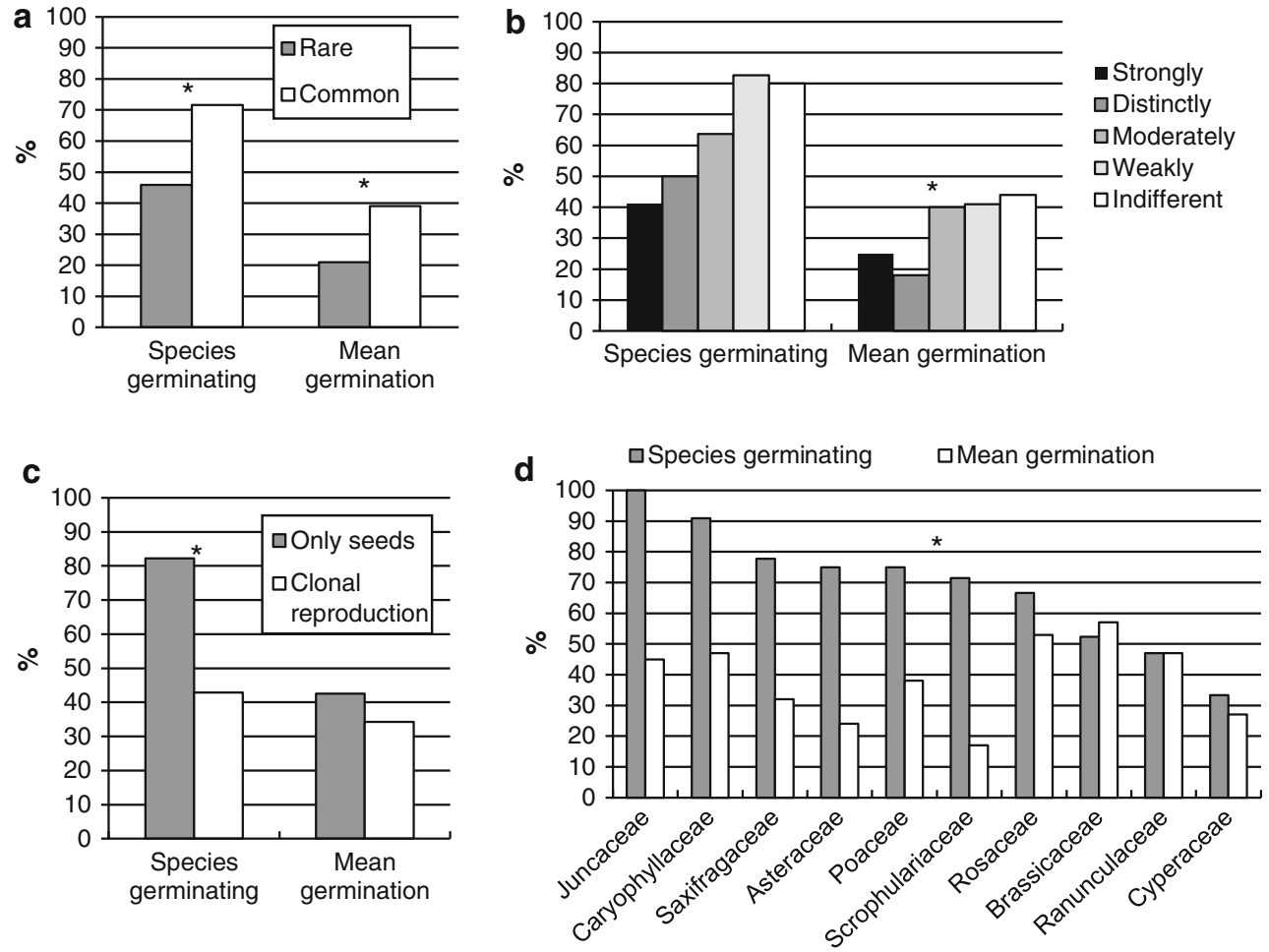

Fig. 2 Effect of species traits on the proportion of species germinating $(n \leq 113)$ as well as mean germination percentage of species with ripe seeds $(n \leq 79)$. a Rarity in Svalbard, b thermal requirements, $\mathbf{c}$ ability to reproduce clonally, and $\mathbf{d}$ plant family (only families with at least three species included, see Table 1). Effect of traits on species germination was tested separately for the proportion of species germinating and mean germination percentages. Significant effects $(p<0.05$, Table 3$)$ are indicated by stars. The star in $\mathbf{d}$ applies to mean germination only

Table 3 Effect of rarity, clonal reproduction, family, and species on germination in 79 species from Svalbard analysed by linear mixed effect model (LME)

\begin{tabular}{|c|c|c|c|c|c|c|c|}
\hline No. & Model term & $d f$ & Deviance & AIC & $\mathrm{BIC}$ & $\chi^{2}$ & $p$ \\
\hline 1 & $y \sim$ Rarity $*$ Clonal $+(1 \mid$ Family/Species $)$ & 6 & 753.50 & 782.1 & 803.4 & & \\
\hline 2 & $y \sim$ Rarity + Clonal $+(1$ Family/Species $)$ & 5 & 754.80 & 781.7 & 799.5 & 1.621 & 0.203 \\
\hline
\end{tabular}

Model simplification for the given data with two predictor variables (fixed effects) and Family as random effect and Species nested in Family as random effect. No. model number, $d f$ degree of freedom, AIC Akaike information criterion, BIC Bayesian Information Criterion, $\chi^{2}$ for model comparison. The AIC, BIC, and number of variables show that model 2 fits the data best

Appendix 3 of Electronic supplementary material). Similarly, the proportion of species that germinated was higher in common than rare species $(z=-2.008 ; p=0.045)$ as well as non-clonal than clonal species $(z=-2.800$, $p=0.005)$, whereas there was no effect of the thermophily or family on the proportion of species that germinated ( $p>0.05$, Fig. 2).

No interaction between the predictor variables was found and the interaction term was removed from the model without significant differences between the models (Table 3). The result of the final model is that the predictor variable (rarity) had a significant influence on germination proportions (Table 3). The proportion of germinated seeds in rare species was significantly lower than the proportion of seeds germinating from common species $(z$ value $=$
$-2.680 ; p=0.007$ ). The second predictor variable (main reproduction mode) had also a significant influence on germination proportions. A significantly larger proportion of the seeds germinated from species that is not reproducing clonally compared to the proportion of seeds that germinated from species with a clonal reproduction option $(z$ value $=-2.113 ; p=0.035)$. Overall, the uniform result of the GLMs and the LME (Tables 2, 3) is, beside the strong influence of species and family traits, that rarity has the strongest influence on seed germination.

Comparison with other studies

In total, 51 of the species studied here had also been studied by Eurola (1972). The following species characterized as 
having no viable seeds based on a tetrazodium test by Eurola (1972), germinated in our study: Carex lachenalii (14\%), C. ursina (62\%), Hierochlöe alpina (14\%), and Stellaria humifusa (94\%); in contrast, no ripe seeds of Poa glauca, Poa pratensis ssp. alpigena, Polemonium boreale, or Stellaria longipes were found in either of the studies (Appendix 3 of Electronic supplementary material). In addition, the following species that did not germinate in the study by Eurola (1972) did germinate in our study: Cassiope tetragona ssp. tetragona, Dryas octopetala, Minuartia rubella, Ranuculus nivalis, Micranthes hieracifolia ssp. hieracifolia, and Saxifraga hirculus ssp. compacta. The mean germination percentages for the 51 species were six times higher in our study (36\%) compared to Eurola (6\%).

The mean germination percentages were higher in the study by Müller et al. (49\%) than in this study (34\%, $n=22$ ). Lack of germination in three thermophilous species as observed by Alsos et al. (2003) was also observed in this study. Germination percentages were similar to Hagen (2002) for Bistorta vivipara and Dryas octopetala, but lower in our study for the three other species (Appendix 3 of Electronic supplementary material).

There were 67 species also studied by Sørensen (1941). All 37 species that germinated in Sørensen's study also germinated in our study except Betula nana, Euphrasia wettsteinii, and Minuartia biflora. Ten of 15 species that did not germinate in Sørensens's study germinated in our study. In addition, six of 15 species were Sørensen found no ripe seeds, germinated in our study (Appendix 3 of Electronic supplementary material).

\section{Discussion}

The proportion of species with viable propagules (79 with seeds and eight with bulbils of 113 species) and the germination percentages obtained (mean $35 \%$ ) are both high compared to some previous studies from Svalbard (Appendix 3 of Electronic supplementary material) and other Arctic regions (Sørensen 1941; Bliss 1958), and more in accordance with other reports from the Arctic (Mooney and Billings 1961; Bliss and Gold 1999; Müller et al. 2011). Thus, the ability to bank propagules of Arctic species for future restoration and conservation purposes is generally high. The low proportion $(<50 \%)$ of rare species germinating is of concern, as they are of highest conservation need, and alternative management strategies to seed banking and in situ conservation must be sought.

The generally improved germination observed in this study compared to Eurola (1972) could be partly due to improved stratification and germination treatment technique applied in our study, but also due to a greater temperature sum during the year of our study (1 May-30
September 2008 , 489.6 K, mean $3.2^{\circ} \mathrm{C}$ ) in comparison with Eurola (1 May-30 September 1969, 376.0 K, mean $2.5^{\circ} \mathrm{C}$ ). Also, the higher proportion of species that germinated in our study compared to Sørensen's study (Sørensen 1941) strengthens the view that germination in Arctic species is increasing due to current climate warming (Müller et al. 2011).

Germination in relation to rarity, thermal requirements, and clonality

The strong association between rarity and thermophily suggests that thermal requirements limit recruitment in rare plants, which in turn limit their distribution. Rare and thermophilous species also do not germinate from natural Arctic seed banks (Cooper et al. 2004). However, germinability may vary strongly among years (Laine et al. 1995), and sexual reproduction may occur only in infrequent, favourable years, as indicated by the levels of genetic diversity found in some rare, thermophilous species (Alsos et al. 2002). For some species, poor recruitment could be due to factors other than thermal constrains. In the species of assumed hybrid origin, Carex lidii and Eriophorum $\times$ sorensenii, lack of seeds could be due to problems with chromosome paring as observed in other hybrids (Comai 2005). In Carex marina ssp. pseudolagopina and Coptidium pallasii, lack of germination may be due to difficulties in breaking dormancy, as physiological and morphophysiological dormancy probably is evident in each of these species, respectively (Baskin and Baskin 2001). In the hemiparasite Euphrasia wettsteinii, which most regularly set ripe seeds in Svalbard as it is annual, host stimulus is not required but germination may be sensitive to stratification conditions (Liebst and Schneller 2008).

In contrast, the unexpected high germination percentages recorded in some rare and thermophilous species indicate that distribution of rare species may be limited by factors other than germinability of seeds. Juncus albescens, of which $91 \%$ seeds germinated in this study, could be limited by factors such as availability of rich mire sites (cf. (Elvebakk 1994)), whereas Carex krausei, which had a germination rate of $67 \%$, could be a recent immigrant that has further dispersal potential as it has only recently been discovered at two sites in Svalbard (Artsdatabanken 2010). The relatively high germination percentage (28\%) of the endemic, assumed apomictic species Ranuculus wilanderi (Jonsell 2001), is based on 18 seeds only: due to the small population size (Artsdatabanken 2010), the total seed production is low and may constrain any spread of this endangered species. For all three species, also the seedling survival stage may be limiting, as seedling survival may be low even in common species (Karsdóttir and Aradóttir 2006). Low seedling survival in nature may, however, not 
be a problem for management purposes as high survival rates may be obtained in horticulture as observed for $R$. wilanderi, which is now conserved ex situ in Troms $\varnothing$ Arctic-Alpine Botanical Garden.

As we have collected seeds mainly in the warmest sites of Svalbard, we missed rare species that are cold tolerant. However, most rare species are thermophilous. Among the 54 species on the redlist for Svalbard (Artsdatabanken 2010), 30 are classified as strongly thermophilous, 11 as distinctly thermophilous, and two as moderately thermophilous (Elvebakk 1989). Further, four are classified as weakly thermophilous and five are unclassified by Elvebakk (1989). Only Draba pauciflora and Puccinellia vahliana, both near threatened, are classified as temperature indifferent. The latter germinated to $52 \%$ in our study indicating that cold tolerant rare species may be limited by other factors than temperature.

Lack of germinable seeds in 23 common species was unexpected. It is unlikely that they obtained their current distribution in Svalbard (Alsos et al. 2012a) by vegetative reproduction alone. Exceptions are Cerastium regelii, Puccinellia phryganodes ssp. villfoidea, and Stellaria longipes, which achieve efficient dispersal by shoots (and possible Poa pratensis ssp. alpigena, where the relationship between viviparous and seminiferous forms is unclear, Elven et al. 2011). Although ten of the species are somewhat thermophilous and may only reproduce infrequently (Carex parallela ssp. parallela, C. saxatilis, ssp. laxa, Coptidium lapponicum, Eriophorum triste, Deschampsia sukatschewii ssp. borealis, Poa glauca, Polemonium boreale, Salix reticulata, Petasites frigidus ssp. frigidus, and Pedicularis dasyantha var. dasyantha), the other ten are rather hardy and thus not expected to be constrained by the current climate. For Carex nardina ssp. hepburnii and C. fuliginosa ssp. misandra, the germination failure may be related to breaking of dormancy, as this can be problematic in sedges generally (Budelsky and Galatowitsch 1999; Schütz 2000). Five of the species, Alopecurus borealis, Festuca rubra ssp. richardsonii, Minuartia biflora, Pedicularis dasyantha var. dasyantha, and Saxifraga platysepala, germinated to low percentages from seeds or seed banks in other studies from Svalbard (Eurola 1972; Cooper et al. 2004; Müller et al. 2011), indicating that the lack of ripe seeds or germination in our study may be due to, for example, annual variation. Similarly, for Arctophila fulva, Cardamine polemonioides, and Saxifraga aizoides, lack of ripe seeds can also be a result of annual variation, although we are not aware of any other germination tests of these species from Svalbard. For the latter one, sexual reproduction must take place as it has no means of clonal reproduction.

The higher proportion of non-clonal than clonal species germinating was expected as non-clonal species rely on reproduction by seeds for long-term survival, and due to the trade-off between biomass investment in generative and vegetative plant structure (Herben et al. 2012). Lack of germinable seeds in ten non-clonal may be related to unripe seeds in the year of study or difficulties of breaking dormancy as discussed above. Also, delimitation of clonality is not straightforward (Klimešová and Doležal 2011), and even species that we classified as non-clonal following Brochmann and Steen (1999) may regenerate by short lateral shoots as, for example, the tussock forming grass Deschampsia sukatschewii ssp. borealis. Species may also survive for long periods due to high age as, for example, Betula nana (up to 147 years, Miller 1975) and may therefore sustain a population even with infrequent reproduction.

\section{Perspectives for seed banking}

The overall high germination rate (71-100\%) of bulbils confirms that this is an efficient means of recruitment. Thus, bulbils may be useful at least for short-term storage. For the bulbil producing species studied here, storing seeds may not be an alternative as no seeds of these species have been observed in Svalbard (Brochmann and Håpnes 2001; Alsos et al. 2012a). Only Poa pratensis is commonly semeniferous, but no ripe seeds were found (Table 1). Thus, future test should be undertaken to determine if the bulbils remain viable even after some years of storage and are thus useful for ex situ conservation in seed vaults.

Of the species for which seeds were found but germination failed or was low, the viability of the seeds should be checked, for example, using a Tetrazodium test (Peters 2007). If the seeds are viable, different stratification and germination conditions should be tested. While the majority of cold adapted species produced viable seeds and thus are relatively easy to collect for a seed bank, most thermophilous species failed to produce viable seeds. To overcome the limitations caused by low temperatures, successful seed production could be obtained by artificially warming the plants using, for example, open top chambers (Klady et al. 2011). Although we expect that global warming on the long term will have a positive effect on recruitment in most of these species as it may increase seed production and viability (Klady et al. 2011), there is a risk that the species will get lost under current climate if both population sizes and/or levels of genetic diversity are low (Alsos et al. 2002, 2007; Frankham et al. 2009). Thus, ex situ conservation in, for example, botanical gardens should be used to conserve the current genetic diversity found in Arctic populations. As this requires a large effort per species, species should be prioritized according to Red List status.

For non-clonal species without viable seeds, ex situ conservation in, for example, botanical gardens may be 
challenging. However, seeds may ripe in botanical gardens due to more optimal conditions. Also, propagation of new plants from cuttings is a well-established method in horticulture and has been successful also for non-clonal species from the Arctic (Hagen 2002).

The longevity of seeds should be tested repeatedly. Seeds from cool, wet conditions are shorter lived than those from hot, dry environments (Probert et al. 2009), and germinability is reduced over time in alpine species (Mondoni et al. 2011). In seeds of Arctic species, however, germinability may be retained over long periods by seed storage at freezing temperatures (Billings and Mooney 1968), although the report of germination of 10,000 year old Lupinus arcticus seeds (Porsild et al. 1967) is disputed (Godwin 1968; Gugerli 2008).

For species with low germination percentages, whether this is due to low proportion of viable embryos or due to lack of knowledge of adequate germination methods, larger amount of seeds should be collected to ensure sufficient amount of seeds that are likely to germinate. To account for annual variation, collections should be done over several seasons. Also, for all species seeds from more populations should be collected to obtain a representative cover of the total genetic diversity of the species. While ideally seeds from the entire range should be collected, populations likely to go extinct due to climate change, as identified by, for example, species distribution models (Alsos et al. 2012b), should be targeted (Vitt et al. 2010). For Arctic species, species distribution modelling indicates that these will mainly be populations at the southern parts of their ranges (Parmesan 2006; Alsos et al. 2012b).

\section{Conclusions}

As the proportion of species germinating and their germination percentages were higher than assumed by many previous studies, seed banks may be a viable strategy for ex situ conservation also of the Arctic flora. Improved knowledge of seed ecology and ongoing climate warming are two factors that likely contribute to the high germination. Sampling of seeds should cover a broad geographical range, paying especially attention to regions where populations are expected to extirpate due to climate change, to obtain seeds representative for the majority of the genetic diversity within species. For species without viable seeds, alternative methods of ex situ conservation need to be evaluated.

Acknowledgments We thank all people that assisted in collecting, cleaning, and counting seeds (see Appendix 1 of Electronic supplementary material), UNIS for logistic support, Linsay Robb at the Millenium Seed Bank Project for suggestions regarding germination methods of individual species, Charmain Hamilton, Andrea Schmidt,
Claire Bouree, Maarten de Korte, Bente Sved Skottvoll, and Elke Morgner for help with seed germination, Reidar Elven for checking identification of species, and Chris Ware for editing the language. We thank Svalbard Environmental Foundation for financial support to Alsos (08/26: NOK 110.000 and 09/17: NOK 47.000), which were used to fund field and laboratory assistance. The Governor of Svalbard is thanked for permit to collect plant material for scientific use (2007/00521-2).

Open Access This article is distributed under the terms of the Creative Commons Attribution License which permits any use, distribution, and reproduction in any medium, provided the original author(s) and the source are credited.

\section{References}

ACIA (2006) Arctic climate impact assessment-scientific report. Cambridge University Press, Cambridge

Acock AC, Gordon RS (1979) A measure of association for nonparametric statistics. Soc Forces 57:1381-1386

Alsos IG, Engelskjøn T, Brochmann C (2002) Conservation genetics and population history of Betula nana, Vaccinium uliginosum, and Campanula rotundifolia in the arctic archipelago of Svalbard. Arct Antarct Alp Res 34:408-418

Alsos IG, Spjelkavik S, Engelskjøn T (2003) Seed bank size and composition of Betula nana, Vaccinium uliginosum, and Campanula rotundifolia habitats in Svalbard and northern Norway. Can J Bot 81:220-231. doi:10.1139/b03-018

Alsos IG, Eidesen PB, Ehrich D, Skrede I, Westergaard K, Jacobsen GH, Landvik JY, Taberlet P, Brochmann C (2007) Frequent long-distance colonization in the changing Arctic. Science 316:1606-1609. doi:10.1126/science.1139178

Alsos IG, Arnesen G, Sandbakk BE, Elven R (2012a) The flora of Svalbard. http://svalbardflora.net. Accessed 2012

Alsos IG, Ehrich D, Thuiller W, Eidesen PB, Tribsch A, Schönswetter P, Lagaye C, Taberlet P, Brochmann C (2012b) Genetic consequences of climate change for northern plants. Proc R Soc Lond B 279:2042-2051. doi:10.1098/rspb.2011.2363

Artsdatabanken (2010) Norsk rødlistevurdering for arter 2010 (The 2010 Norwegian red list for species). www.artsdatabanken.no. Accessed 2012

Baskin CC, Baskin JM (2001) Seeds: ecology, biogeography, and evolution of dormancy and germination. Academic Press, London

Bell KL, Bliss LC (1980) Plant reproduction in a high arctic environment. Arct Alp Res 12:1-10

Billings WD, Mooney HA (1968) The ecology of arctic and alpine plants. Biol Rev 43:481-529

Birks HH, Paus A, Svendsen JI, Alm T, Mangerud J, Landvik JY (1994) Late Weichselian environmental change in Norway, including Svalbard. J Quat Sci 9:133-145

Bliss LC (1958) Seed germination in arctic and alpine species. Arctic 11:180-188

Bliss LC, Gold WG (1999) Vascular plant reproduction, establishment, and growth and the effects of cryptogamic crusts within a polar desert ecosystem, Devon Island, N.W.T., Canada. Can J Bot 77:623-636

Brochmann C, Håpnes A (2001) Reproductive strategies in some arctic Saxifraga (Saxifragaceae), with emphasis on the narrow endemic S. svalbardensis and its parental species. Biol J Linn Soc 137:31-49

Brochmann C, Steen SW (1999) Sex and genes in the flora of Svalbard-implications for conservation biology and climate change. Det Norske Videnskaps-Akad I Mat Naturv K1, Skr, Ny serie $38: 33-72$ 
Brooker RW, Carlsson BÅ, Callaghan TV (2001) Carex bigelowii Torrey ex Schweinitz (C. rigida Good., non Schrank; C. hyperborea Drejer). J Ecol 89:1072-1095. doi:10.1111/j. 1365-2745.2001.00623.x

Budelsky RA, Galatowitsch SM (1999) Effects of moisture, temperature, and time on seed germination of five wetland Carices: implications for restoration. Restor Ecol 7:86-97. doi:10.1046 /j.1526-100X.1999.07110.x

Collett D (2003) Modelling binary data. Chapman \& Hall/CRC, London

Comai L (2005) The advantages and disadvantages of being polyploid. Nat Rev Gen 6:836-846

Cooper EJ, Alsos IG, Hagen D, Smith FM, Coulson SJ, Hodkinson ID (2004) Recruitment in the Arctic: diversity and importance of the seed bank. J Veg Sci 15:115-124. doi:10.1111/j.1654-1103. 2004.tb02244.x

Coulson SJ, Refseth D (2004) The terrestrial and freshwater invertebrate fauna of Svalbard (and Jan Mayen). In: Prestrud P, Strøm H, Goldman H (eds) A catalogue of the terrestrial and marine animals of Svalbard. Norwegian Polar Institute, Troms $\varnothing$, pp 57-122

Dormann CF, Albon SD, Woodin SJ (2002) No evidence for adaptation of two Polygonum viviparum morphotypes of different bulbil characteristics to length of growing season: abundance, biomass and germination. Polar Biol 25:884-890

Elvebakk A (1989) Biogeographical zones of Svalbard and adjacent areas based on botanical criteria. PhD thesis, University of Troms $\varnothing$, Troms $\varnothing$

Elvebakk A (1994) A survey of plant associations and alliances from Svalbard. J Veg Sci 5:791-802

Elven R, Elvebakk A (1996) Part 1. Vascular plants. In: Elvebakk A, Prestrud P (eds) A catalogue of Svalbard plants, fungi, algae, and cyanobacteria, vol 198. Norsk Polarinstitutt Skrifter. Norsk Polarinstitutt, Oslo, pp 9-55

Elven R, Murray DF, Razzhivin V, Yurtsev BA (2011) Checklist of the Panarctic Flora (PAF). CAFF/University of Oslo. http://gbif.no/paf. Accessed 2012

Engelskjøn T, Lund L, Alsos IG (2003) Twenty of the most thermophilous vascular plant species in Svalbard and their conservation state. Polar Res 22:317-339

Eurola S (1972) Germination of seeds collected in Spitsbergen. Ann Bot Fenn 9:149-159

Frankham R, Ballou JD, Briscoe DA (2009) Introduction to conservation genetics, 2nd edn. Cambridge University Press, Cambridge

Godwin H (1968) Evidence for the longevity of seeds. Nature 220:708-709

Gugerli F (2008) Old seeds coming in from the cold. Science 322:1789-1790. doi:10.1126/science.322.5909.1789b

Hagen D (2002) Propagation of native Arctic and alpine species with a restoration potential. Polar Res 21:37-47. doi:10.1111/j.17518369.2002.tb00065.x

Herben T, Nováková Z, Klimešová J, Hrouda L (2012) Species traits and plant performance: functional trade-offs in a large set of species in a botanical garden. J Ecol 100:1522-1533. doi: 10.1111/j.1365-2745.2012.02018.x

Hodkinson ID, Webb NR, Bale JS, Block W, Coulson SJ, Strathdee AT (1998) Global change and arctic ecosystems: conclusions and predictions from experiments with terrestrial invertebrates on Spitsbergen. Arct Alp Res 30:306-313

Jonsell B (ed) (2001) Chenopodiaceae-Fumariaceae, vol 2. Flora Nordica. The Bergius Foundations, The Royal Swedish Academy of Science, Stockholm

Karsdóttir L, Aradóttir ÁL (2006) Propagation of Dryas octopetala L. and Alchemilla alpina L. by direct seedling and planting of stem cuttings. Icel Agric Sci 19:25-32
Klady RA, Henry GHR, Lemay V (2011) Changes in high arctic tundra plant reproduction in response to long-term experimental warming. Glob Chang Biol 17:1611-1624. doi:10.1111/j.13652486.2010.02319.x

Klimešová J, Doležal J (2011) Are clonal plants more frequent in cold environments than elsewhere? Plant Ecol Div 4:373-378. doi: 10.1080/17550874.2011.586734

Laine K, Malila E, Siuruainen M (1995) How is annual climatic variation reflected in the production of germinable seeds of arctic and alpine plants in The Northern Scandes? In: Oechel WC, Callaghan T, Gilmanov $\mathrm{T}$ et al (eds) Global change and Arctic terrestrial ecosystem, vol 10. Ecosystem Research report. European Commission, Springer, New York, pp 89-95

Liebst B, Schneller J (2008) Seed dormancy and germination behaviour in two Euphrasia species (Orobanchaceae) occurring in the Swiss Alps. Bot J Linn Soc 156:649-656

Miller HJ (1975) Anatomical characteristics of some woody plants of the Angmagssalik district of southeast Greenland. Geosci Biosci 198:30

Mondoni A, Probert RJ, Rossi G, Vegini E, Hay FR (2011) Seeds of alpine plants are short lived: implications for long-term conservation. Ann Bot 107:171-179. doi:10.1093/aob/mcq222

Mooney HA, Billings WD (1961) Comparative physiological ecology of arctic and alpine populations of Oxyria digyna. Ecol Monogr 31:1-29

Müller E, Cooper EJ, Alsos IG (2011) Germinability of arctic plants is high in perceived optimal conditions but low in the field. Botany 89:337-348. doi:10.1139/b11-022

Murray DF (1987) Breeding systems in the vascular flora of Arctic North America. In: Urbanska KM (ed) Differentiation patterns in higher plants. Academic Press, London, pp 239-262

Parmesan C (2006) Ecological and evolutionary responses to recent climate change. Annu Rev Ecol Evol Syst 37:637-669. doi: 10.1146/annurev.ecolsys.37.091305.110100

Peck JR, Yearsley JM, Waxman D (1998) Explaining the geographic distributions of sexual and asexual population. Nature 391:889-892

Peters J (ed) (2007) Tetrazodium testing handbook, vol 29. The handbook of seed testing. Association of Official Seed Analyst, Las Cruces

Pimentel D (ed) (2011) Biological invasions. Economic and environmental cost of alien plant, animal, and microbe species, 2nd edn. CRC Press/Taylor \& Francis, Boca Raton/London

Porsild A, Harington C, Mulligan G (1967) Lupinus arcticus Wats. grown from seeds of Pleistocene age. Science 158:113-114

Probert RJ, Daws MI, Hay FR (2009) Ecological correlates of ex situ seed longevity: a comparative study on 195 species. Ann Bot 104:57-69. doi:10.1093/aob/mcp082

R Core Team (2012) R: a language and environment for statistical computing. Foundation for Statistical Computing, Vienna

Sala OE, Stuart Chapin F III, Armesto JJ, Berlow E, Bloomfield J, Dirzo R, Huber-Sanwald E, Huenneke LF, Jackson RB, Kinzig A, Leemans R, Lodge DM, Mooney HA, Oesterheld MN, Poff NL, Sykes MT, Walker BH, Walker M, Wall DH (2000) Global biodiversity scenarios for the year 2100. Science 287: 1770-1774. doi:10.1126/science.287.5459.1770

Schütz W (2000) Ecology of seed dormancy and germination in sedges (Carex). Perspect Plant Ecol Evol Syst 3:67-89. doi: 10.1078/1433-8319-00005

Solstad H, Elven R, Alm T, Alsos IG, Bratli H, Fremstad E, Mjelde M, Moe B, Pedersen O (2010) Kaplanter Pteridophyta, Pinophyta, Magnoliophyta. In: Kålås JA, Henriksen S, Skjelset S, Viken Å (eds) Norsk rødliste for arter 2010 (The 2010 Norwegian red list for species). Artsdatabanken, Trondheim, pp 155-182

Sørensen T (1941) Temperature relations and phenology of the northeast Greenland flowering plants. Medd Grønl Geosci 125:1-305 
Söyrinki N (1939) Studien über die generative und vegetative Vermehrung der Samenpflanzen in der alpinen Vegetation Petsamo-Lapplands. II. Spezieller Teil. Ann Bot Soc Zool Bot Fenn Vanamo 14:1-404

Talbot S, Yurtsev BA, Murray DF, Argus GW, Bay C, ELvebakk A (1999) Atlas of rare endemic vascular plants of the arctic. Conservation of Arctic Flora and Fauna (CAFF) technical report, vol 3. U.S. Fish and Widlife Service, Anchorage

Thuiller W, Lavergne S, Roquet C, Boulangeat I, Lafourcade B, Araujo MB (2011) Consequences of climate change on the tree of life in Europe. Nature 470:531-534. doi:10.1038/nature09705

Vitt P, Havens K, Kramer AT, Sollenberger D, Yates E (2010) Assisted migration of plants: changes in latitudes, changes in attitudes. Biol Conserv 143:18-27. doi:10.1016/j.biocon.2009. 08.015
Walck JL, Cofer MS, Hidayati SN (2010) Understanding the germination of bulbils from an ecological perspective: a case study on Chinese yam (Dioscorea polystachya). Ann Bot 106:945-955. doi:10.1093/aob/mcq189

Ware C, Bergstrom D, Müller E, Alsos I (2012) Humans introduce viable seeds to the Arctic on footwear. Biol Invasions 14: 567-577. doi:10.1007/s10530-011-0098-4

Wehrmeister RR, Bonde EK (1977) Comparative aspects of growth and reproductive biology in arctic and alpine populations of Saxifraga cernua L. Arct Alp Res 9:401-406

Wookey PA, Robinson CH, Parsons AN, Welker JM, Press MC, Callaghan TV, Lee JA (1995) Environmental constraints on the growth, photosynthesis and reproductive development of Dryas octopetala at high Arctic polar demi-desert, Svalbard. Oecologia 102:478-489 